\title{
28. SEDIMENTARY SEQUENCES OF THE TIMOR TROUGH, TIMOR, AND THE SAHUL SHELF
}

\author{
J. J. Veevers, Macquarie University, Sydney, N.S.W., Australia
}

Geological information from Timor (Audley-Charles, 1968), from drilling along the outer part of the Sahul Shelf, and from drilling at the axis of the Timor Trough at Site 262 is presented in the stratigraphic columns of Figure 1, in time versus depositional environment curves in Figure 2, and in a set of paleogeographical maps in Figure 3.

The Neogene history of Timor (Audley-Charles, 1968) starts with the deposition of shallow (Cablac) and deeper-water (Aliambata) limestone in the early Miocene. During the Ramelauean orogeny in the middle Miocene, thrust sheets were emplaced from the north and were overlain by olistostromes of the Bobonaro scaly clay, which were deposited in deep water. Then, during the late Miocene, the island of Timor started to rise (Soro Uplift), and the regressive marine Viqueque Formation was deposited through the early Pliocene and was capped by the Soketo Block Clay and Dilor Conglomerate. Then, following a phase (Mataian) of folding, the Suai Formation was deposited along the south coast of Timor, and fringing reefs formed along the north coast. With continued uplift, these reefs were raised to their present maximum elevation today of 1283 meters.

On the other side of the present Timor Trough, on the outer edge of the Sahul Shelf, shallow marine carbonate rocks were deposited in the early Miocene and probably during at least the early part of the middle Miocene. These were partly stripped off during uplift that continued into the early Pliocene. This area then subsided, and during the rest of the Pliocene and the Quaternary shallow marine carbonates were accumulated. The surface on which this younger sequence of sediments rests is Reflector $1\left(R_{1}\right)$ of Veevers et al. (in preparation). At BOC Sahul Shoals-1, this surface is dolomitized.

Drilling at Site 262 showed that very shallow-water carbonate, in part dolomitized and of early Pliocene age,

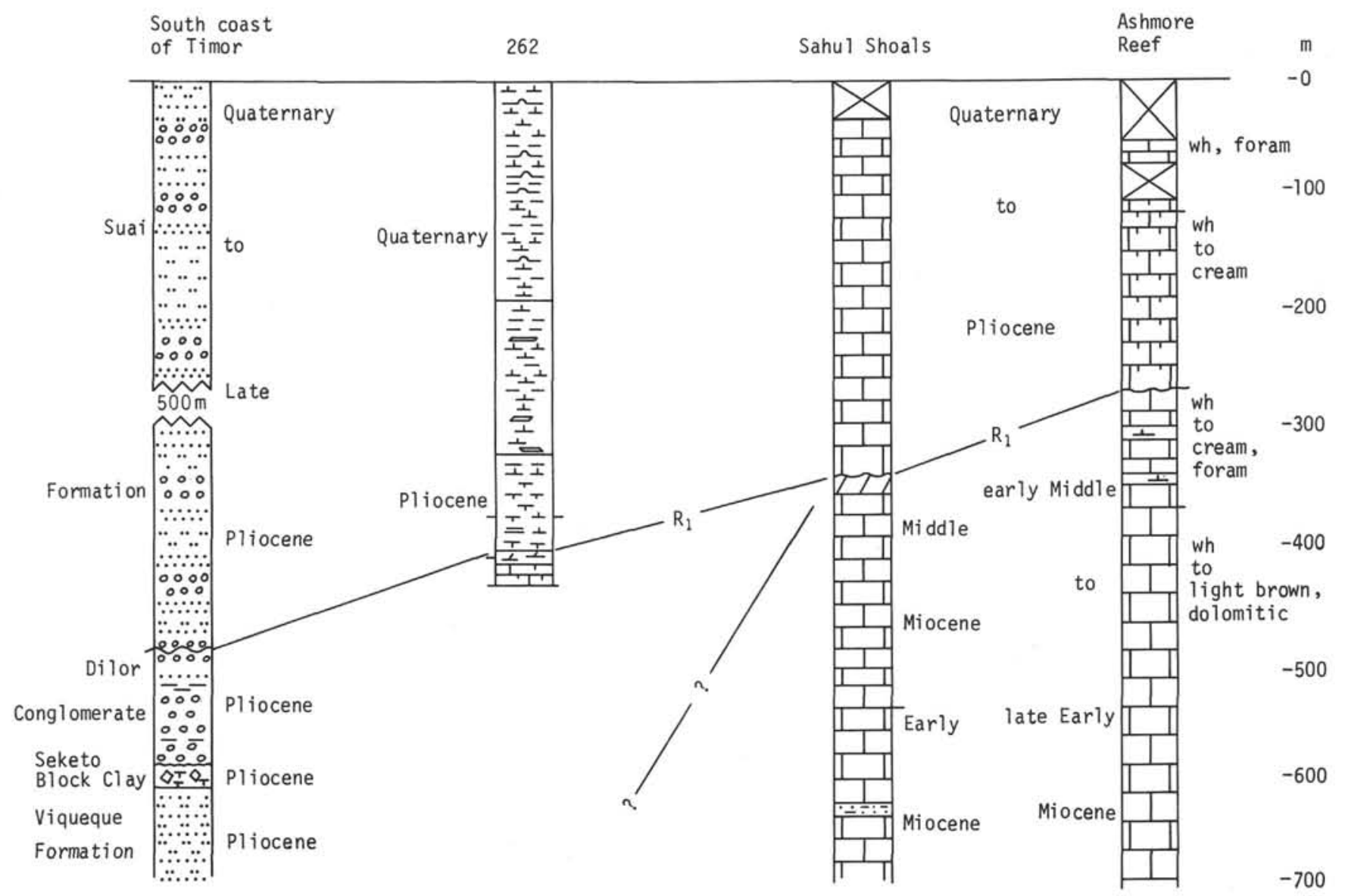

Figure 1. Generalized stratigraphic columns from the Timor Trough and vicinity. 


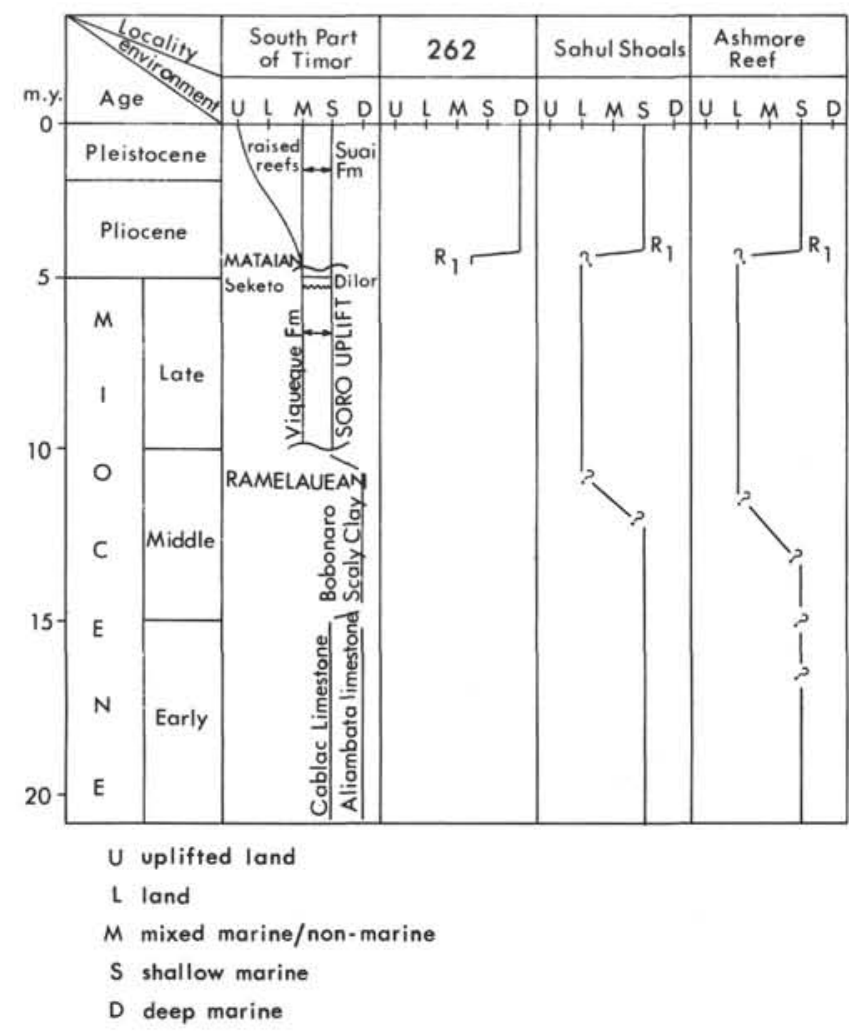

Figure 2. Interpreted depositional environments of sediments from Site 262 and adjacent areas. is overlain above a short interval of transition strata, by Pliocene and younger deeper-water ooze. The boundary between the shallow and deeper water carbonates corresponds with the reflector, $R_{1}$.

A paleogeographical synthesis of this information is shown in Figure 3. The present geography (Figure 3D) developed from the early Pliocene inception of Timor and the Timor Trough. Earlier in the Pliocene and Miocene, the present area of Timor was a chain of ridges and basins, and the Timor Trough was presumably a shallow sea.

Audley-Charles et al. (1972) explain the Neogene tectonics of Timor as a sequence of collisions at a trench north of the leading edge of the Australian continental block (represented by Timor) with successive volcanic arcs.

\section{REFERENCES}

Audley-Charles, M. G., 1968. The geology of Portuguese Timor: Mem. Geol. Soc. London, v. 4.

Audley-Charles, M. G. and Carter, D. J., 1972. Paleogeographic significance of some aspects of Paleogene and early Neogene stratigraphy and tectonics of the Timor Sea region: Paleogeogr. Paleoclimatol. Paleoecol., v. 11, p. 247 264.

Audley-Charles, M. G., Carter, D. G., and Milsom, J. S., 1972. Tectonic development of eastern Indonesia in relation to Gondwanaland dispersal: Nature Phys. Sci., v. 239, p. $35-39$.

Veevers, J. J., Windisch, C. C., and Falvey, D. A., in preparation. Timor Trough-A modern fore deep. 
A. $15-10$ m.y. Bp Middle Miocene

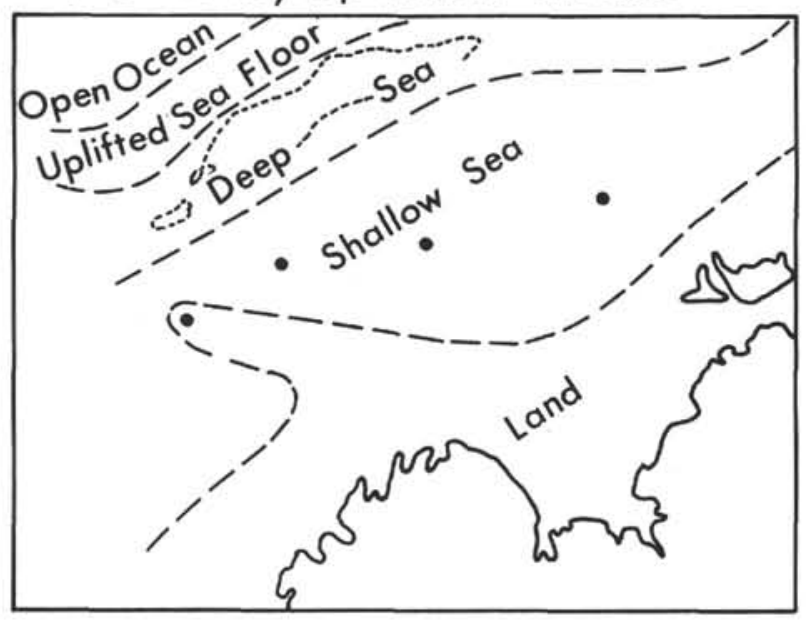

B. 10-5 m.y. Bp Late Miocene

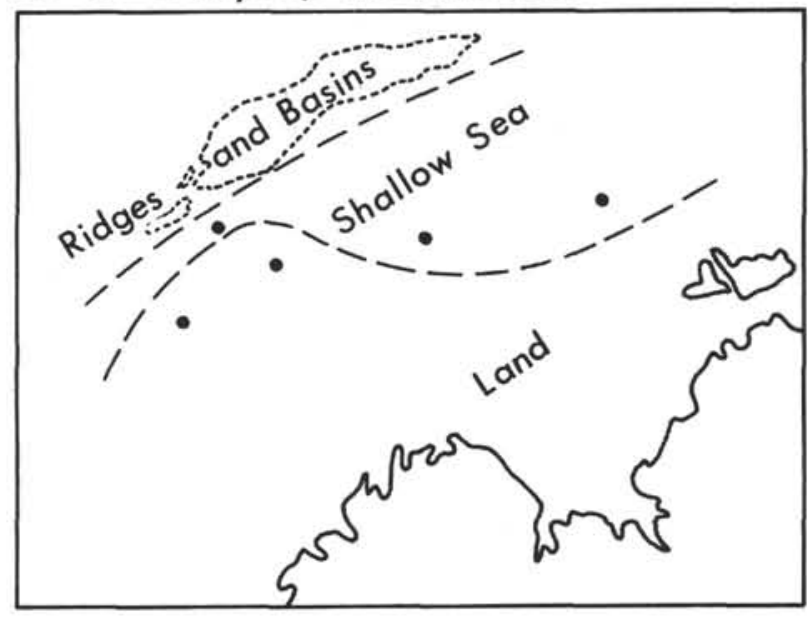

C. 5-2 m.y. Bp Pliocene

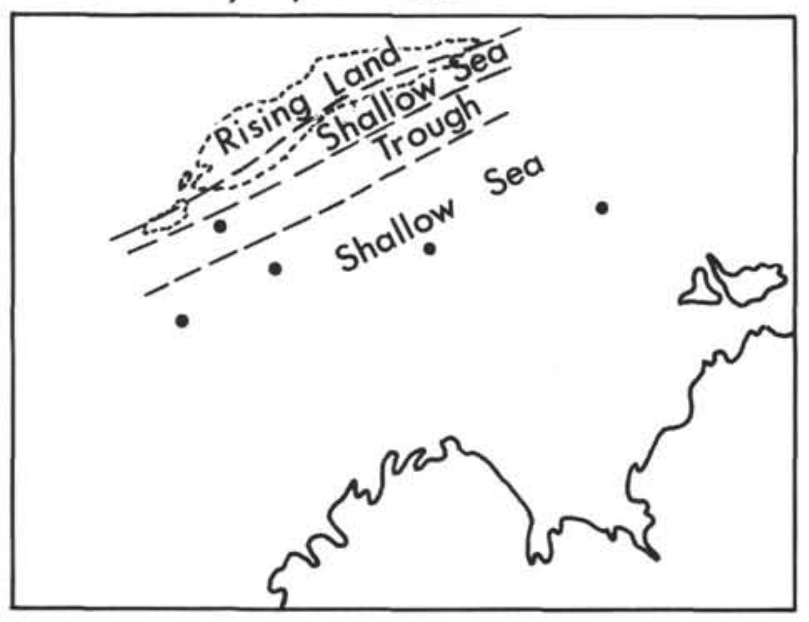

D. Present

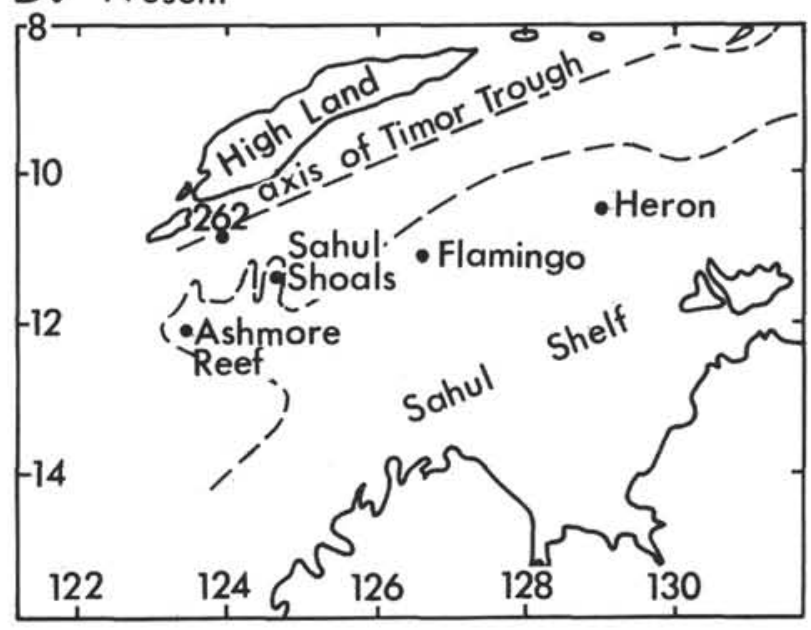

Figure 3. Paleogeographic maps of the Timor Trough area from middle Miocene to Present. 